\title{
Bailarinas e bailarinos: uma etnografia da dança como profissão*
}

\author{
Juliana Cunha Lima Neves ${ }^{* *}$
}

\begin{abstract}
Resumo
$\mathrm{O}$ artigo investiga os fatores de atração para a dança, atividade para a qual é atraída uma minoria que faz do corpo instrumento de trabalho e recurso de transgressão das próprias condições de existência. Bailarinas e bailarinos foram tomados aqui como objeto pertinente $e$ desafiador para uma análise socioantropológica, na medida em que a sua figura $e$ a sua adesão profissional ao meio coreográfico trazem à tona elementos relativos às tensões entre classe, gênero, atuação artística e desvios de trajetórias, que devem ser explorados a ter como ponto de partida o corpo, portador privilegiado das marcas sociais.
\end{abstract}

Palavras-chave: Dança, Corpo, Gênero, Sexualidade, Trabalho.

" Recebido para publicação em 14 de outubro de 2011, aceito em 28 de junho de 2012.

** Pós-doutorado em Sociologia da cultura pela Universidade de São Paulo, FFLCH.

cadernos pagu (41), julho-dezembro de 2013:201-238. 
Bailarinas e bailarinos: uma etnografia da dança como profissão

Women and Men Dancers: Ethnography of Dancing as a Profession

\begin{abstract}
This paper studies the factors attracting to dancing, activity that lures a minority that uses the body as both labor instrument and resource for transgression of its own conditions of existence. Dancers are here taken as pertinent and challenging objects for a socio-anthropological analysis in so far as their figure and professional choice brings to surface elements relative to the tensions surrounding class, gender, artistic performance and route deviations that ought to be explored, having as a point of departure the body, as major carrier of social marks.
\end{abstract}

Key Words: Dance, Body, Gender, Sexuality, Labor. 


\section{Introdução}

Este artigo trata da relação entre vocação artística e grupos sociais, por meio de um estudo sobre a dança, atividade para a qual é atraída uma minoria de pessoas que faz do corpo instrumento de trabalho e recurso de transgressão das próprias condições de existência. Bailarinas e bailarinos foram tomados aqui como objeto pertinente e desafiador para uma análise socioantropológica, na medida em que a sua figura e a sua adesão profissional ao meio coreográfico trazem à tona elementos relativos às tensões entre classe, gênero, atuação artística e desvios de trajetórias, que devem ser explorados a ter como ponto de partida o corpo, portador privilegiado das marcas sociais (Bourdieu, 2007:162).

A investigação reside nos principais fatores objetivos $e$ subjetivos de atração para a dança, mais precisamente, aqueles que mobilizam bailarinos amadores ao ingresso, à permanência $e$ à devoção dessa prática na sua dimensão profissional. Ofício socialmente definido como feminino, que ocupa posição dominada entre as atividades de trabalho mais consideradas do universo masculino e também do meio da cultura, a dança, além de ser pouco reconhecida como profissão, implica muitos sacrifícios. Trata-se de uma carreira bastante concorrida e curta por conta das restrições impostas pelo envelhecimento do corpo ,cujas recompensas materiais não são expressivas e os espaços que garantem estabilidade de emprego são limitados. Sem contar a ligação entre o bailarino e o seu corpo caracterizada pela violência, brutalidade, riscos, machucados e sofrimento.

Não obstante, esse é um métier envolvido de mistérios e encantamentos que fascina um pequeno número de um conjunto amplo de amadores. Após anos de dedicação a essa prática, muitos bailarinos, inclusive os que conquistaram nível técnico profissional, deixam a dança para seguir outras carreiras. Mas, há também os que permanecem e que passam a vivenciá-la como um trabalho, na condução metódica da vida. A pesquisa examina 
Bailarinas e bailarinos: uma etnografia da dança como profissão

quem são, do ponto de vista social, os portadores da dança como profissão e, sobretudo, quais os elementos de sedução mais significativos que justificam compensar os martírios $e$ as penitências do corpo e de levar adiante esse projeto de vida.

Nesse sentido, tomei como cenário analítico o contexto coreográfico atual da cidade de São Paulo, centro da dança no país, em que são encontrados bailarinos de distintos perfis alinhados em diferentes modelos estéticos: de um lado, a produção contemporânea que tem como base os procedimentos do balé clássico e, de outro, as linguagens da vanguarda amparadas, sobretudo, nas técnicas de improvisação. Contudo, o foco deste artigo se ajusta ao primeiro segmento da dança, em razão da situação estável e da legitimidade de seus grupos, da visibilidade de sua produção e também da importância da formação clássica do corpo, tanto para a criação contemporânea tradicional como para as pesquisas mais radicais e inovadoras do movimento. ${ }^{1}$

No que diz respeito à metodologia, optei pela etnografia como recurso para a construção de um conjunto de dados que permitisse reflexões antropológica e sociológica sobre o tema em questão. Para tanto, realizei um estudo de caso na Cisne Negro Cia. de Dança (1977), companhia considerada das mais tradicionais da cidade. Na investigação, procedi à observação de campo por meio de um diário, no qual descrevi a rotina de trabalho e as experiências vivenciadas no corpo. Além disso, fiz o registro fotográfico das aulas, dos ensaios e do espetáculo que redundou do processo criativo pesquisado; e a análise dessas

\footnotetext{
1 Em São Paulo funcionam seis companhias estáveis de dança. Duas ligadas ao Estado: a recém-criada São Paulo Cia. de Dança patrocinada pelo governo do Estado e o Balé da Cidade de São Paulo financiado pela Prefeitura. As outras Ballet Stagium, Cia. Sociedade Masculina, Studio 3 Cia. e a Cisne Negro Cia. de Dança - não dependem da ajuda exclusiva do Estado e buscam recursos não só para os espetáculos, mas para a manutenção da companhia, principalmente, no mecenato ou na iniciativa privada, na bilheteria e nas leis de incentivo à cultura.
} 
imagens. E realizei entrevistas com parte dos bailarinos que integravam a Companhia. ${ }^{2}$

Ao entrar no ambiente do Cisne Negro tem-se a sensação de estar fora do mundo, em um universo à parte da vida cotidiana. E, no momento de minha imersão, tive de abandonar também os compromissos de meu dia a dia e me aclimatar ao ritmo profissional do grupo. Acompanhei as aulas $e$ os ensaios,conversei com os professores, bailarinos e funcionários, me alimentei pouco e rápido como os bailarinos e me submeti a uma disciplina fora dali que permitia cumprir a rotina da Companhia e estar presente e concentrada para uma relação de confronto e absorção daquela realidade.

Quando se está numa atmosfera em que o elemento central é o corpo ocorre que o pesquisador torna-se um corpo a mais daquele ambiente, bastante perceptível $e$ alvo de questionamentos. Não foram poucas as pessoas que se dirigiram a mim para afirmarem que eu já havia sido bailarina, o que facilitou minha aceitação e diminuiu desconfianças. ${ }^{3}$ Mas, essa percepção junto à observação de aulas e ensaios e a convivência no Cisne Negro, reativaram, em mim, uma hexis corporal do passado que automaticamente mantive e que amenizou a identidade de pesquisadora, um corpo estranho $e$ intruso inserido no meio de um espaço sempre cercado de corpos. Isso significa dizer que não abandonei o meu corpo somente ao papel de pesquisadora: que observa, faz anotações, marca reuniões, aplica entrevistas. Para estar presente e assimilar, a um só tempo, aquele mundo, andei, sentei, me movimentei, gesticulei, conversei também como bailarina. Desse modo, me posicionei como "bailarina pesquisadora" o que estabeleceu um singular "corpo a corpo" no processo de registro.

2 Na época da pesquisa a Cisne Negro Cia. de Dança era composta por vinte e dois bailarinos, entre profissionais e estagiários. Com o intuito de organizar uma amostra das narrativas entrevistei doze bailarinos (seis mulheres e seis homens).

3 Fui durante quatorze anos bailarina amadora de dança clássica. 
Bailarinas e bailarinos: uma etnografia da dança como profissão

Também vivenciei os ritos do teatro, por ocasião da apresentação do espetáculo Fruto da Terra; Cherché, Trouvé, Perdu; Trama no Sesc Vila Mariana, em São Paulo. Passei um dia acompanhando os bastidores da apresentação. A aula de balé clássico no teatro, os ensaios já no palco, as marcações no chão, o estudo da luz, o clima das coxias e dos camarins, o problema dos figurinos, o comportamento e a administração do capital corporal dos bailarinos e toda aquela tensão contagiante que envolve a atmosfera das artes do espetáculo quando se está a poucas horas de abrir as cortinas e se deparar com o público.

A pesquisa de campo terminou com a minha observação, na plateia, da apresentação do espetáculo. Não só o meu antigo contato com o meio e com a situação de palco, mas também o fato de eu ter acompanhado o processo de trabalho viabilizaram uma análise mais sensível dos bailarinos nessas condições. Por outro lado, tinha já o conhecimento das trajetórias de vida de alguns dos integrantes da Companhia, o que me fez compreender e objetivar na dimensão profissional dos bailarinos, o que Heloisa Pontes chamou atenção a respeito de Cacilda Becker e das grandes atrizes do teatro,

que fazendo de seus corpos o suporte privilegiado para a reconversão de experiências alheias, dominam as convenções teatrais a ponto de burlar constrangimentos sociais de classe, gênero $e$ idade, infundindo às personagens uma pletora de significados novos $e$ inesperados (Pontes, 2010:25).

Os bailarinos que integram a Cisne Negro Cia. de Dança têm um mês de férias e durante o resto do ano trabalham de terça a sexta-feira, das $9 \mathrm{~h}$ às $15 \mathrm{~h}$ na sede da Companhia, na Vila Beatriz. Pontualidade, disciplina, energia física e habilidade mental são qualidades que dizem respeito ao ritmo desses profissionais compassado pelo momento da aula de balé clássico, pelos ensaios das coreografias e por dois intervalos de meia hora. Além da 
atuação no teatro. A Cisne Negro Cia. de Dança apresenta em média setenta espetáculos por ano, não só na cidade de São Paulo, mas no interior do Estado e no litoral, e circula com as temporadas pelo Brasil e no exterior.

\section{O corpo e a rotina de trabalho ${ }^{4}$}

\section{Sensuelle solitude}

O sol suave da manhã ilumina o ambiente calmo $e$ descontraído da sala de trabalho que começa a ser ocupada pelos bailarinos, que se abraçam $e$ se beijam de um modo afetivo $e$ conversam enquanto se alongam e se aquecem, antes do início da aula de balé clássico e das atividades do grupo. O professor, ao chegar, cumprimenta alguns bailarinos e a pianista, que arruma as partituras no piano e posiciona-se para começar a tocá-lo.

Já no primeiro acorde os bailarinos estão organizados na frente do espelho e fazem uma série decorada de alongamento. Depois se encaminham para as barras e a música leve e agradável embala os corpos em um movimento sincronizado, preciso $e$ concentrado. A pedagogia do balé clássico limita-se à observação $e$ à reprodução do que é elaborado pelo professor. E é ao memorizar, repetir e executar os movimentos que os bailarinos fazem a aquisição das técnicas corporais próprias dessa dança. Para adquirir forma física e técnica profissionais são anos de dedicação, já para perdê-las é questão de semanas. De modo que o treino diário de balé clássico é imprescindível para a manutenção de seus procedimentos.

4 É possível que o sentido e a sensualidade da dança sejam de difícil apreensão para o leitor que vai ingressar no mundo dos bailarinos por intermédio da escrita. Um dos obstáculos que diz respeito à sociologia da música ou do boxe, por exemplo, reside em retraduzir as sensações dessas práticas em outra linguagem. Nas páginas que seguem busquei realizar essa tarefa com a dança, por meio de um exercício que procurou estreitar a atenção ao meu corpo de bailarina amadora e a observação de campo no universo profissional dessa atividade (Wacquant, 2002:90). 
Na Cisne Negro Cia. de Dança há uma diferença entre homens e mulheres no que tange a essa educação. Os primeiros, diferentemente das bailarinas, entram em contato com o balé clássico mais tarde e depois de já terem praticado outras modalidades de dança como a contemporânea, o jazz, o hip-hop ou mesmo ritmos como o Miami.

A aula tem duração de uma hora e meia e se divide entre os exercícios da barra e do centro. Apesar da atenção requerida, do controle matemático do corpo, da exaustiva repetição e do esforço físico que mobilizam a execução dos movimentos clássicos, os bailarinos se deslocam hábeis e flexíveis em uma tranquilidade calculada e em sóbrio equilíbrio. Com uma das mãos sobre a barra, de olhos fechados e sensuais, os corpos, ao processar a efetivação dos passos, exprimem quietude, energia contida $e$ muito prazer. $\mathrm{Na}$ interiorização dessas tecnologias os bailarinos travam com o próprio corpo uma relação singular de intimidade, tensão, força e sexualidade. O espaço corporal torna-se um cosmo em si mesmo, que no instante de atuação, apesar e em função das dores, isola-se e afasta-se do mundo para atingir a sensação sublime e paradoxal de uma sensuelle solitude.

Entre o sexo, o balé e a solidão há muitas afinidades, como mostra Judith Hanna, ao citar o bailarino Steve Paxton:

algumas das qualidades que têm feito do balé [...] a segunda entre as mais antigas tradições físicas profissionais é uma primitiva infusão de modos fisiologicamente fundamentais do uso da energia, que acho semelhante ao êxtase da distensão, tal como é experimentado em certos tipos de orgasmo... uma distensão positiva e energizada... Todo mundo sabe o que é a síndrome de 'contração e liberação' de Graham, em toda parte [...] a difundida distensão do balé é semelhante à distensão orgástica, não somente em posição, mas na energia empregada para chegar até aí e ficar aí (Hanna, 1999:224). 
O prazer suscitado pela sexualidade interna ao corpo, pela emoção da música e dos deslocamentos físicos e pela prática do exercício virtuoso, que leva a transposição do espaço social, diz respeito também às relações de poder que os bailarinos estabelecem com o corpo ao adquirir o domínio técnico do balé clássico. Articulados, esses elementos promovem sensações de ânimo $e$ liberdade que são secretas ao bailarino $e$ que se estendem, redimensionadas, ao corpo que já foi codificado pela dança. Sentada no chão da sala entre mochilas e sacolas, atrás do piano e cercada por bailarinos em movimento me tornei alvo desse particular sentimento que ao ganhar forma em meu inconsciente alterava também à geometria de meu corpo, que introduzido naquela atmosfera passou a forjar uma corporalidade do passado e se despertar para as percepções corporais do universo coreográfico.

À medida que a aula avança os passos tornam-se cada vez mais difíceis e os bailarinos começam a transmitir os sinais do esforço despendido, antes, imperceptíveis. Já com a respiração em novo ritmo e suados, depois de uma rápida pausa de descanso $e$ alongamento, eles passam para os exercícios do centro. Nessa etapa, o corpo ganha dinâmica mais acelerada por meio de sequências mais ágeis, de apreensão do espaço aéreo sem o suporte das barras, de saltos e giros. E o bailarino que antes se movia concentrado, tenso e leve progride em velocidade, mecanicismo e domínio técnico e é levado ao entusiasmo e a necessidade de colocar o corpo em ação.

No final do treino, que contempla alongamento, musculação e resistência aeróbica, todos, apesar de cansados e por vezes doloridos, apresentam outro estado de espírito. Estimulados e sensibilizados, os bailarinos terminam a aula com uma salva de palmas, assobios e "bravos" para o professor. 
Bailarinas e bailarinos: uma etnografia da dança como profissão
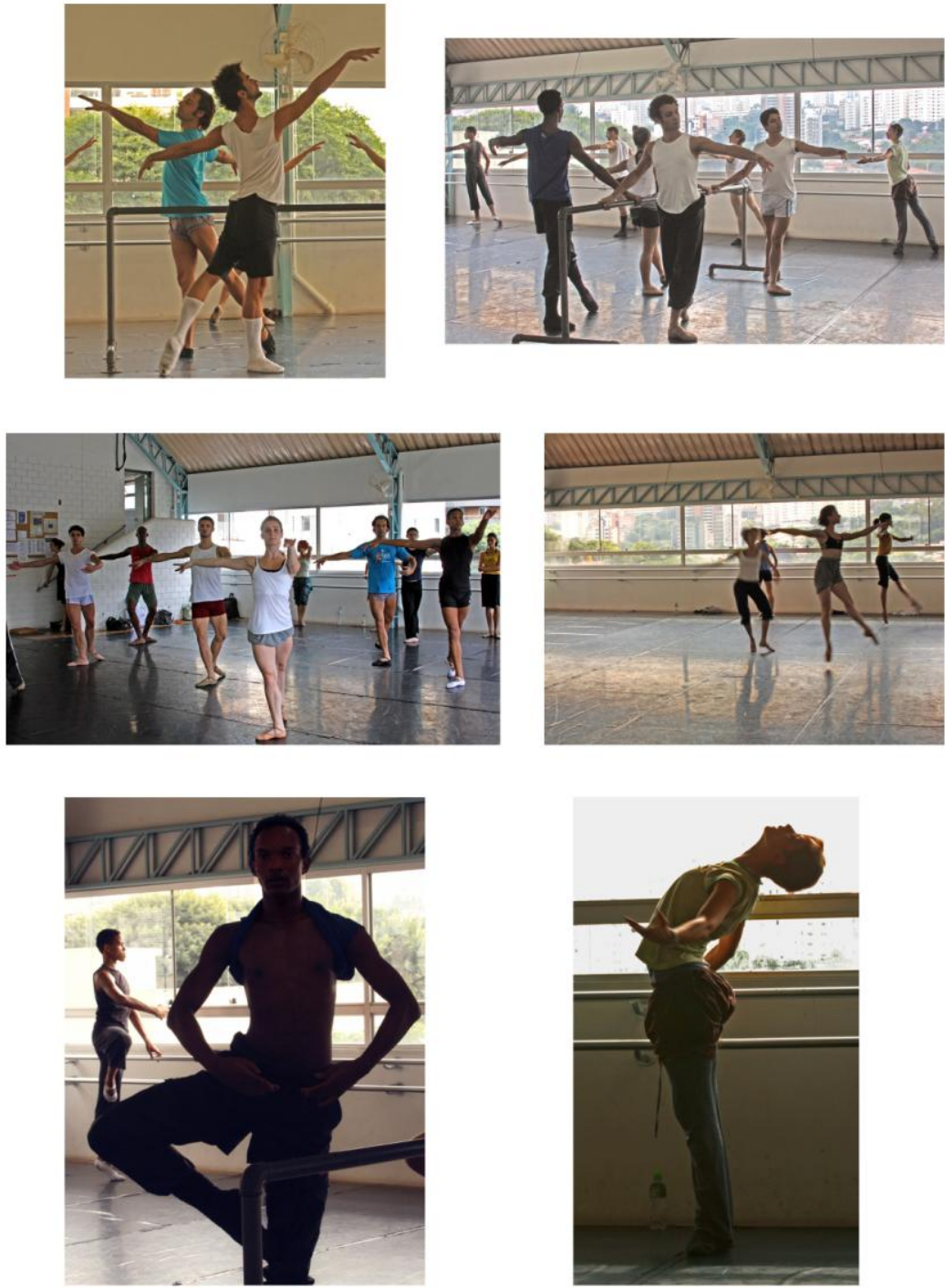
Juliana Cunha Lima Neves
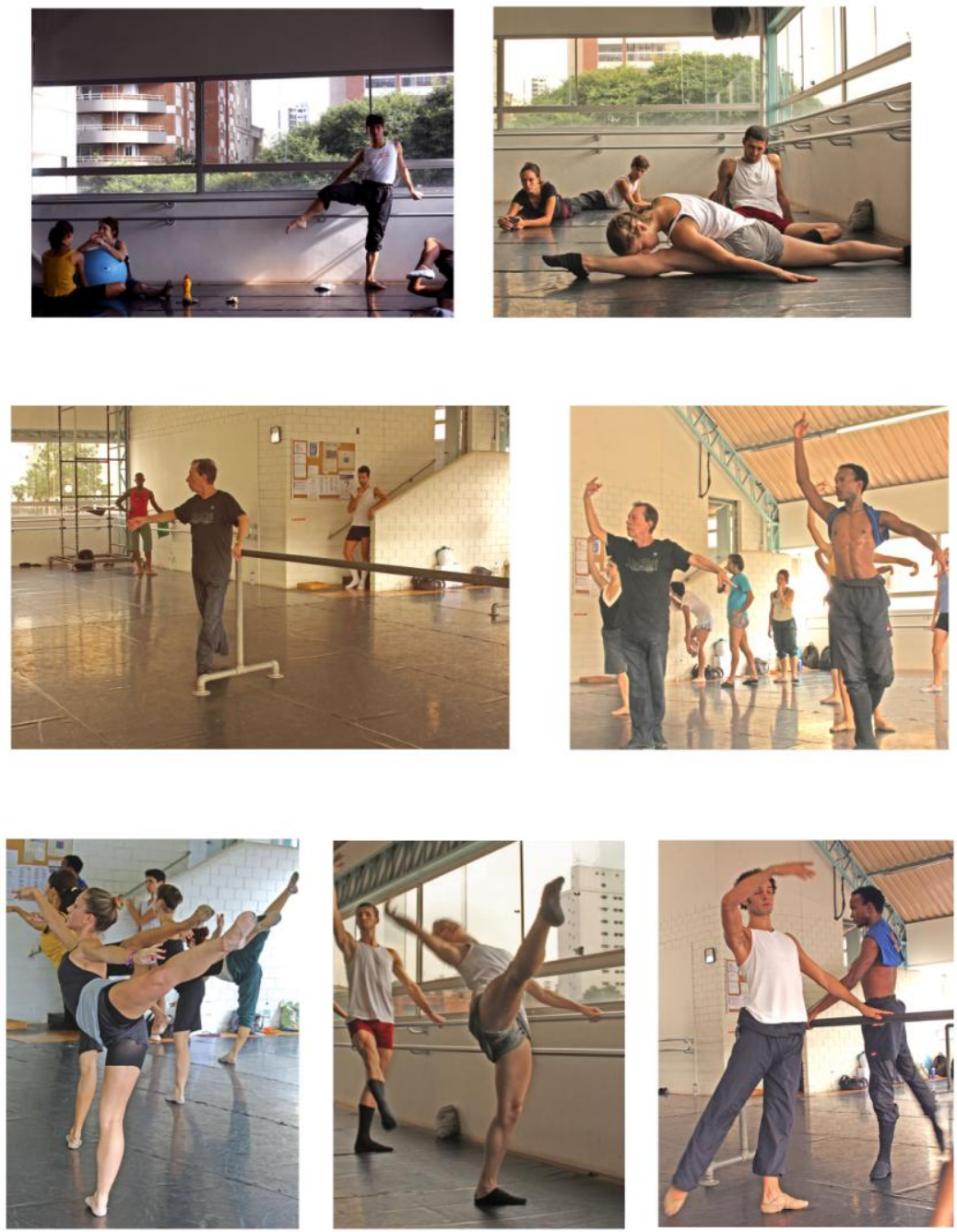
Bailarinas e bailarinos: uma etnografia da dança como profissão

\section{Femininos e masculinos ${ }^{5}$}

As disposições físicas e estéticas obtidas por esses bailarinos nas aulas diárias e na atuação em espetáculos de balé clássico são redimensionadas e submetidas a outras condições corporais. É no trabalho dos ensaios das coreografias de dança contemporânea $e$ na atividade do palco que os bailarinos adquirem a forma pesada, forte e musculosa que caracteriza o corpo atlético daqueles que ingressam como profissionais na Cisne Negro Cia. de Dança.

A diretora de ensaio da Cia. e sua assistente sentam-se em suas cadeiras e ligam pelo controle remoto o som. A música alta e contagiante desperta os bailarinos que começam a se movimentar agitando-se entre o ar e o chão, entrelaçando-se, saltando, segurando-se, correndo, atirando-se no tablado, rodopiando, desenhando formas precisas, rápidas e interativas que transmitem aos espectadores a emoção física e metal que toma os corpos no instante da atuação.

Nas imagens 1 e 2, as bailarinas balançam o corpo, que é embalado, numa sensualidade controlada, pela música. Os olhos fechados, a face exprimindo tranquilidade e prazer, as cabeças levemente inclinadas, as mãos relaxadas sobre as pernas, depois em posição de um baile solitário, fazem parte de um conjunto mais amplo, energizado, que naquele instante da coreografia parece estar em uma concentrada relação de intimidade com sua vida interior e com o manejo de seu corpo. Nesse transe corporal, as bailarinas deixam-se levar pelo movimento e, no momento seguinte, $\mathrm{V}$ desloca-se no pique de passos rápidos e ágeis para lançar-se no ar em um grand jeté espetacular (imagem 3). As pernas e os pés esticados, a barriga pressionada para dentro e a coluna posicionada desenham um corpo em seu domínio, que no salto arriscado e virtuoso se mantem alto, veloz e elástico no ar. Antes da queda, na permanência da subida, sustentada por uma

\footnotetext{
5 As imagens analisadas estão numeradas e apresentadas, nas páginas 23 e 24, e os bailarinos foram identificados com a primeira letra de seus nomes próprios.
} 
incrível habilidade técnica, resistência e grande esforço físico, o rosto da bailarina enrubesce e sua expressão deforma-se; e os cabelos, jogados para cima pelo vento, expandem eriçados. De volta à terra, a bailarina, ainda em velocidade, brilhante de suor, transforma novamente a feição do rosto que se reorganiza esboçando uma altiva placidez avermelhada. Disso, $V$ passa a transitar pela coreografia em um visivel estado corporal alterado denunciado pelas energia, leveza e soltura com que realiza os movimentos.

Com as mãos atiradas para cima, os dois bailarinos da imagem 4, voam alto e executam também grands jetés, que parecem dominar a gravidade. O primeiro, todo de preto, demonstra segurança, virtuosismo e facilidade em executar o passo. O segundo arqueia a sobrancelha compenetrado na sensação de frisson produzida pelo exercício que o leva às alturas.

As técnicas corporais pressupostas nesse estilo de dança contemporânea, que também se utiliza dos procedimentos do balé clássico, estão mais de acordo com disposições próprias do corpo masculino, o que faz com que as mulheres, ao superar as dificuldades de uma prática cuja força e resistência físicas correspondem mais a corporalidade dos homens - embora seja considerada principalmente feminina -, submetam seus corpos a um visível processo de masculinização. Virtuosismo, sensualidade e riscos mobilizam os homens $e$ as mulheres às tensões físicas $e$ espirituais que desencadeiam o estado de êxtase, que faz com que os corpos se desloquem ágeis e emocionados. No entanto, o esforço, o domínio e a emoção que caracterizam esse tipo de dança são vivenciados de modos distintos por bailarinos e bailarinas.

A dança contemporânea promoveu uma mudança importante no que diz respeito à redefinição dos papéis feminino $e$, sobretudo, masculino na performance coreográfica. O corpo feminino, antes, aparentemente, delicado, magro e desenhado com linhas definidas e alongadas do balé clássico, ganha vigor, firmeza e virilidade. Já com os homens ocorre um processo de feminização, na medida em que o corpo passa a ser o vetor de 
Bailarinas e bailarinos: uma etnografia da dança como profissão

expressões de desejos, sofrimentos e do "eu profundo" (Sorignet, 2004:13,14).

Ao ingressarem na Companhia, as mulheres precisam aprender a se movimentar de um modo diferente e a conquistar maturidade na interpretação. Mas, essa apreensão é mobilizada pela longa experiência com o balé clássico, com a qual adquiriram consciência técnica do corpo e desenvoltura artística do espírito. E as bailarinas entrevistadas, todas heterossexuais, não se depararam com o conflito entre a construção do corpo e a experiência da homossexualidade, assumida, nas entrevistas, por boa parte dos bailarinos. Os homens têm mais proximidade com a dança contemporânea e com os elementos que a orientam como a investigação de si mesmo, tornando viável que a elaboração coreográfica do corpo seja explorada na chave dessa dimensão da sexualidade.

$\mathrm{O}$ ambiente predominantemente feminino $e$ a significativa presença de homossexuais na dança fazem com que os bailarinos se sintam seguros e mais à vontade para assumir ou enfrentar as questões da homossexualidade. ${ }^{6}$ Além disso, a dança contemporânea pode ser considerada um veículo que permite aos bailarinos manifestarem os tumultos de uma sexualidade que está em processo de elaboração produzindo com isso sensações de liberdade. Os sentimentos e as pulsões desses jovens artistas são também "apaziguados" no ato de dançar por meio do domínio do corpo, da sublimação da sexualidade e dos castigos físicos atrelados à dança como as dores, os machucados e o esforço despendido, que podem funcionar como recurso de punição às possíveis "conturbações" do corpo. Nesse sentido, as emoções e as sensibilidades do bailarino dizem respeito a um intenso processo de afirmação e das tentativas de explicação da escolha sexual.

6 As razões que dizem respeito à atração que a dança exerce nos homossexuais são investigadas por Hanna (1999a:202, 324). 
No entanto se, de um lado, a dança é um espaço social aberto à homossexualidade, de outro, a possibilidade dos homens de explorar a experiência feminina nesse meio, na busca por liberdade, independência e identidade, é coibida pelos papéis masculinos que os mesmos devem representar.

As coerções físicas que "corrigem" o corpo e a atitude dos homens no ato de dançar, cujos efeitos dizem respeito a uma aprendizagem da masculinidade na cena, não se limitam à dança contemporânea, mas são, principalmente, experimentadas pela lógica perversa e contraditória do balé clássico: a vivência confusa de um corpo que, atraído pela delicadeza feminina, defronta-se com a necessidade de afirmar a sua masculinidade.

Trabalhar as emoções e o domínio do corpo é, portanto, tarefa mais árdua para os bailarinos do que para as bailarinas, ainda que os homens da Companhia tenham mais familiaridade com a dança contemporânea. Os obstáculos para as mulheres dizem respeito ao pouco contato com o estilo contemporâneo $e$ a aquisição de força e resistência masculinas no corpo feminino. Mas, no que tange a esse último aspecto, o corpo das bailarinas já marcado pelas tecnologias da educação do balé clássico, desvia a trajetória e faz aflorar, em outro registro coreográfico, sua configuração masculina. Trata-se, no caso dos homens, de processar no âmbito da prática $e$ da atmosfera da dança a opção pela homossexualidade. Mas, também de construir e vivenciar uma corporalidade masculina na cena.

\section{Dois abraços e os seus desdobramentos}

Quando termina a repetição da coreografia, a diretora de ensaio $e$ sua assistente se levantam e começam a corrigir os bailarinos. O clima apesar de hierárquico é aparentemente ameno, de cooperação e descontraído. Os bailarinos param um pouco, sentam, conversam, trocam de roupas para depois, em um ritmo menos acelerado, começar as atividades. A respiração passa a outra frequência e o corpo transpira o esforço anterior. 
$\mathrm{Na}$ imagem 7, uma dupla de homens treina um abraço. Em um salto inclinado o bailarino cai nos braços de seu parceiro, que o segura vigoroso, sem demonstrar qualquer dificuldade em sustentar o peso do outro. De olhos fechados, entregues ao cansaço da hora, os dois entrelaçam os corpos escorregadios $e$ úmidos em um apaixonado e sofrido encontro. Sensuais $e$ exercitados, os bailarinos se amparam e numa pausa comovida parecem transcender ao ambiente externo aos seus corpos.

Outro par, um homem e uma mulher, outro abraço, porém mais reticente e levemente distanciado (série A). Os corpos quase nus parecem não concluir o enlaçamento. A mão da bailarina não toca por inteiro o bailarino que, por sua vez, deixa o braço solto em suas costas. Um pequeno vão entre os corpos faz com que não se encostem, completando-se. O bailarino, um negro, definido $e$ alinhado prepara-se tenso para iniciar uma sequência perigosa, na qual conduzirá a bailarina branca, musculosa e pesada para cima. De cabelos curtos, tatuada entre a barriga e a virilha, o corpo exposto e coberto apenas por um top roxo e pela calça adidas arregaçada pelo calor, a bailarina prepara-se, autônoma $e$ concentrada, para uma interação em que o seu parceiro será o suporte para a execução de seus arriscados e performáticos movimentos que desenharão no ar as formas de um pássaro alado.

Apreensivo $\mathrm{L}$ segura com força o braço de $\mathrm{C} e$ toca suavemente a sua coxa. A seguir, o bailarino, como ponto de apoio, mantém a mão sob a perna feminina agora suspensa no ar. Independente, o corpo da bailarina começa a ganhar forma e os dois afastam-se estilizados, mas a mão do homem permanece firme segurando ainda a coxa, para que o desligamento não se concretize. Soltam-se e, submisso, L fica de quatro no chão enquanto $\mathrm{C}$, em pleno domínio de seu poderoso corpo, desenvolve a forma da figura alada. Entre os punhos cerrados, o bailarino exprimindo sentimentos de esforço utiliza a outra mão para amparar o traseiro de C e carregá-la até o seu ombro direito, onde, pressionando o púbis, a bailarina se equilibra, com os 
cabelos sob a face, soltando delicadamente as mãos para cima $e$ cruzando levemente as pernas com os pés esticados.

No retorno, perigoso, o braço do bailarino engata o meio das pernas de $\mathrm{C}$ que, de lado, se encaixa em seu ombro e logo está de ponta cabeça, solta, com o corpo abandonado e preso apenas pelo braço fálico de L. A dupla de olhos fechados tensiona intimamente os seus corpos para finalizar a série que termina com a bailarina pendurada de braços abertos, pernas flexionadas e pés esticados nos braços de L, que a sustenta no ar. Os dois ainda de olhos fechados concluem o erótico malabarismo manifestando sensualidade e prazer.

A dança tem o corpo como seu instrumento que é também o suporte da sexualidade. Nas imagens apresentadas o cheiro físico do bailarino exercitado, a proximidade e o contado direto entre os corpos que transpiram, a entrega por inteiro, confiante ou controlada do corpo, a "ilusão e a simulação, íntima, mas distante" (Hanna, 1999b:31) do ato sexual, as formas poéticas desenhadas pelo corpo, as sensações de prazer e domínio e a transposição da existência da realidade imediata provocadas pelo corpo demonstram que a sexualidade é elemento central das relações que os bailarinos estabelecem com seus corpos e com os corpos dos outros que, para além de serem experimentadas na dança entre pares, despertam também o desejo no espectador.

No entanto, a sexualidade não se exprime na dança somente pela presença de um corpo sensual e pelas formas sugestivas de seus movimentos. Mas, os elementos corporais acionados na aprendizagem, no ensaio $e$ no palco produzem $e$ estimulam algo que diz respeito a uma sexualidade interna ao corpo. A força, a concentração, o controle, o sacrifício, o equilîbrio, a distensão, o ritmo e a transgressão que mobilizam o domínio técnico do corpo fazem da dança uma poderosa forma de sublimação sexual (Hanna, 1999c:18). Como na dança a investigação artística se concretiza no corpo, o trabalho e a energia empreendidos fazem da ação coreográfica espaço privilegiado 
Bailarinas e bailarinos: uma etnografia da dança como profissão

para o desvio e a transformação da pulsão sexual, que põe à disposição da atividade cultural

quantidades de força extraordinariamente grandes, $e$ isto graças à particularidade, especialmente acentuada nela, de poder deslocar o seu alvo sem perder, quanto ao essencial, a sua intensidade. Chama-se a esta capacidade de trocar o alvo sexual originário por outro alvo, que já não é sexual, mas que psiquicamente se aparenta com ele, capacidade de sublimação (Laplanche e Pontalis apud Freud, 1986:638). ${ }^{7}$

Ainda do ponto de vista da sexualidade, as imagens da série A são reveladoras de alguns aspectos sobre a dominação feminina e masculina na dança. A bailarina toma a cena, mas move-se com o auxílio da força de seu parceiro que a conduz para o alto e é o seu suporte. Mas é ela que está no controle, inclusive no simulado processo erótico da coreografia. $\mathrm{E}$ nos momentos em que $\mathrm{C}$ desfalece, o seu corpo não está destituído das tensões requeridas para a continuidade da performance. O domínio do corpo, das emoções e da sexualidade das bailarinas diz respeito a uma longa experiência na dança.

Desde a infância ou no início da adolescência, as mulheres, no balé clássico, são submetidas a um treino regular cuja aquisição de disposições corporais implica a capacidade de sublimação sexual, que é desenvolvida e estimulada na medida em que o corpo processa as tecnologias que viabilizam a conquista de seu domínio técnico. No interior do universo "cor de rosa e de fantasia de contos de fadas" do balé, no qual a presença masculina é bastante incipiente, o trabalho cotidiano para a formação da bailarina é mobilizado em muito pelo espírito competitivo que predomina no ambiente da dança, que desperta fortes sentimentos de buscar igualar-se ou superar os pares em posições de prestígio como, por exemplo, o lugar ocupado pela figura da primeira

7 Freud trata dessa questão sobre a sublimação das pulsões eróticas e de agressão no texto O futuro de uma ilusão(1978:87). 
bailarina. ${ }^{8} \mathrm{O}$ "encantamento" com as bailarinas "eleitas" leva a uma rivalidade, que é decisiva para a dedicação sistemática ao exercício disciplinado do corpo que vai torná-lo apto a lutar nos confrontos do meio.

A construção do corpo mecânico do balé implica também um automatismo do espírito alimentado pelo estilo de vida ascético que o produz. E a submissão, a persistência e a disputa são qualidades imprescindíveis para a permanência nessa prática. Para que esse processo se concretize, para que seja levado adiante, as bailarinas precisam desenvolver, para além de uma resistência física masculina, a resistência moral que permitirá que a outra seja conquistada. Ocorre certo "autismo" nessa corporalidade preservado por um enorme controle de si e pela superação da falta de sensibilidade, da inveja, do ciúme, das acirradas competições, das injustiças e preferências que caracterizam as escolas de dança. $\mathrm{O}$ distanciamento com as exigências desse mundo circundante é polarizado pela incessante aquisição e manutenção técnica do corpo. Além disso, a bailarina tem que se defrontar ainda muito jovem com as reflexões de ingresso ou não ao métier; ${ }^{9}$ o que significa também resignar-se ou não a esse universo, sobretudo, feminino, abrindo mão de experiências de vida mais amplas, inclusive as da sexualidade, do mundo lá fora.

Essa rotina do período de aprendizagem é redimensionada no plano profissional. Mais maduras $e$ adultas, as bailarinas passam a atuar em um universo embora competitivo, menos conservador e mais artístico. $\mathrm{O}$ trabalho na dança nessa passagem ganha outros sentidos e se orienta para um modo de vida no qual as experiências do corpo, antes "clássico" na sua forma e no seu

8 A noção de imitação prestigiosa elaborada por Mauss, na qual crianças e adultos imitam os atos bem sucedidos de pessoas que exercem prestígio $e$ autoridade, deve ser em muito considerada no que diz respeito ao processo de aquisição das técnicas corporais na educação da dança clássica (Mauss, 2003:405).

9 Sobre a questão da resistência física e, sobretudo, moral na dança ver o documentário Tout près des étoiles: les danseurs de l'Opéra de Paris de Nils Tavernier. 
Bailarinas e bailarinos: uma etnografia da dança como profissão

espaço, se reorganizam adquirindo novos domínios corporais, de técnicas, das emoções e da sexualidade. A emulação deixa de ter como alvo a abstrata e histriônica figura da primeira bailarina para ser potencializada nas estratégias em destacar-se como artista consagrado no meio da dança, que são, por sua vez, impulsionadas pela alquimia produzida no corpo, sobretudo, pela cena. 
Juliana Cunha Lima Neves
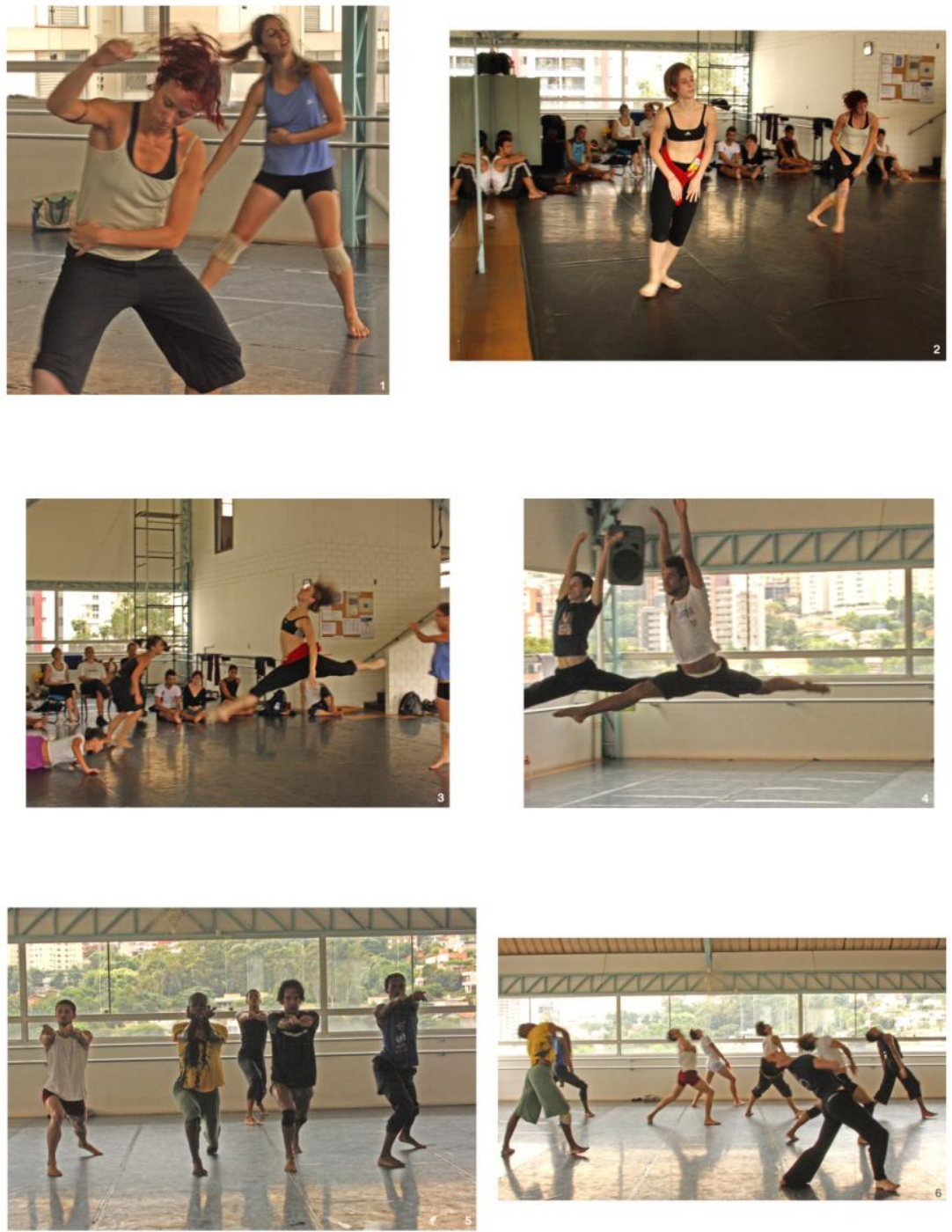
Bailarinas e bailarinos: uma etnografia da dança como profissão

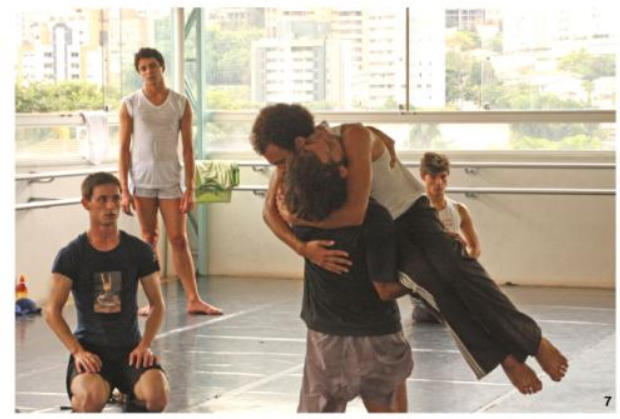

Série A
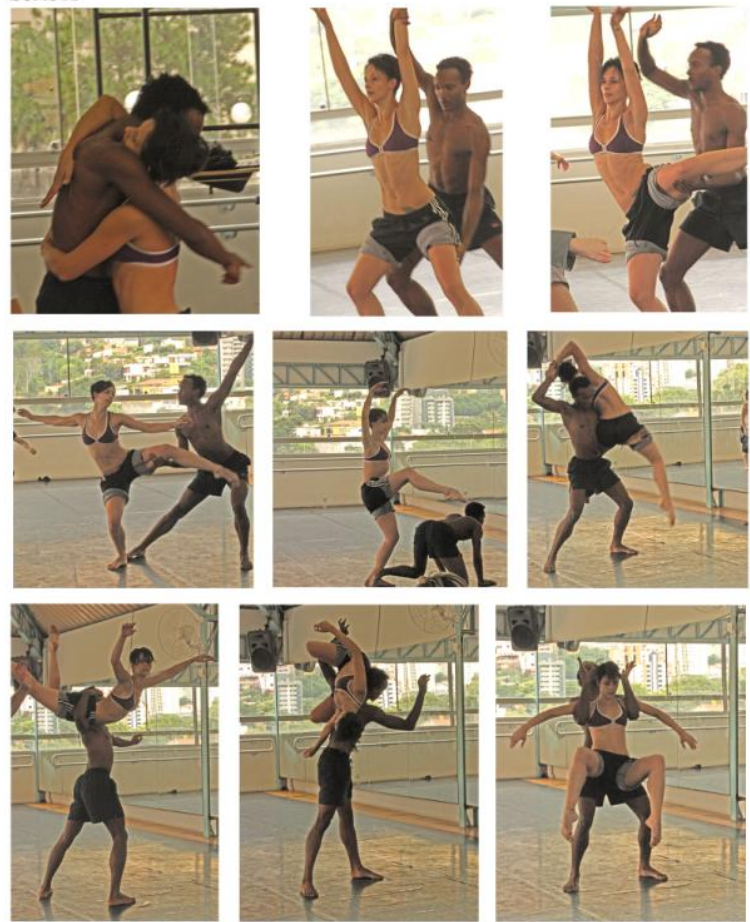


\section{Os ritos do teatro, o espetáculo e as engrenagens do corpo}

No momento em que eu realizava a pesquisa de campo, a Cisne Negro Cia. de Dança ensaiava um programa que seria apresentado em Caraguatatuba, Guarulhos e São Paulo. Além disso, o grupo estava de partida para uma turnê na Alemanha. Fazia parte de minha etnografia acompanhar os bailarinos no teatro observando o dia de trabalho da apresentação e o resultado do espetáculo. Fui encontrá-los em uma quarta-feira à tarde, no Sesc Vila Mariana.

Chego ao teatro e procuro a produção do evento, que me autoriza a entrar na sala onde será o espetáculo e na qual se encontram os bailarinos. Silenciosamente me sento na plateia $e$ começo a assistir à aula de balé clássico, que é realizada no palco e ministrada pela assistente da diretora de ensaio.

Os bailarinos estão visivelmente tensos e o nervosismo só piora no decorrer do ensaio. Ao terminar a aula há uma pausa de meia hora. Nesse momento, eu me encaminho para trás das coxias, alguns bailarinos sobem para o camarim, outros se deitam de olhos fechados, concentrados e buscando tranquilizar-se no chão e no escuro do preto das longas cortinas da coxia, que são levemente iluminadas pelo colorido que vem do palco. Ao redor dos corpos espalhados circulam técnicos de luz e de som, funcionários da Companhia e do Sesc.

Ao ingressar nesse ambiente secreto dos artistas do espetáculo, fui invadida pelas lembranças das apresentações de dança que fiz no teatro, da espera e da preparação do corpo que vai para o palco. Reminiscências: sentada junto com outras jovens bailarinas em uma escada montada e rodeada por estruturas de ferro, no escuro, esperávamos a nossa vez, que se aproximava, de entrar em cena. O espetáculo acontecia no palco e, em uma passagem da música que tocava alta, a professora, correndo, veio nos chamar. De súbito todas se levantaram de fantasias, maquiagem e cabelos arrumados, e apressaram-se, batendo a ponta das sapatilhas no assoalho, para trás das coxias. De lá 
Bailarinas e bailarinos: uma etnografia da dança como profissão

víamos o espetáculo de outro ângulo, tentávamos enxergar o público, saber se a plateia estava cheia e ouvíamos a professora, que perguntava se estávamos preparadas. A música silenciava, era chegada à hora, e baixinho dizíamos, nos colocando nas posições corretas, "merda" umas para outras, que na linguagem do teatro significa sorte.

Minha memória acionou muitos outros momentos de minha breve experiência de teatro ao longo desse dia: o camarim, a preparação do cabelo, a maquiagem, experimentar o figurino já marcado com o meu nome, proteger os pés com esparadrapos $e$ panos para colocar as sapatilhas de ponta. A hora da cena, iluminada, emocionante, concentrada, solitária e muito rápida. Quando você se dá conta já está novamente na coxia. E as sensações inebriantes do retorno ao palco no momento dos agradecimentos com os aplausos da plateia. Sensibilizada $e$ alterada, procurei espantar minhas lembranças e retornar ao meu papel de pesquisadora.

O ensaio ia começar e retornei à plateia na qual estava a diretora da Cia., sentada, chamando os bailarinos por um microfone para repetirem as coreografias junto com a iluminação, os cenários e a música. A diretora faz as correções e os ajustes necessários. Mas no palco os bailarinos não executam para valer os passos. Simplesmente marcam pausadamente a coreografia sem despender esforço, guardando energia para o espetáculo. A administração do capital corporal ocorre em todos os estágios do processo de trabalho dos bailarinos. Contudo, no teatro há muita cautela no que diz respeito à dosagem de força e aos cuidados para não colocar o corpo em risco antes da apresentação.

$\mathrm{Na}$ medida em que o tempo passa e se aproxima a hora do espetáculo, o estresse vai tomando o corpo dos profissionais e dos outros envolvidos. A situação limite do teatro não é só vivenciada como uma tensão negativa. O estado de aflição, de angústia e de viva inquietude é uma experiência prazerosa, que contagia o espírito dos participantes e dos espectadores e que é imprescindível para a atuação no espetáculo. Trata-se de uma 
preparação do corpo e da consciência que vai produzir nos bailarinos exaltação e abstração transportando-os para fora de si e do mundo sensível no instante do palco. O trabalho árduo das aulas e dos ensaios justifica-se, na opinião de uma ex-bailarina da Companhia de Dança da Ópera de Paris, "pela sensação de cinco minutos do espetáculo, que é uma sensação que não tem preço". ${ }^{10}$

Quando o horário do espetáculo se aproxima os bailarinos sobem para o camarim, onde se arrumam, comem alguma coisa, conversam. Eu, na plateia, já lotada, aguardo ansiosa o desfecho do processo. O sinal toca pela terceira vez. As luzes se apagam, o Sesc anuncia a Cisne Negro Cia. de Dança e as cortinas se abrem. Começa o espetáculo.

A primeira coreografia, Fruto da Terra, embora tenha sido concebida pelo israelense Itzik Galili trata do relacionamento, dos conflitos e das tensões entre camponeses da América Latina, que dançam a vida, a lida no campo, a dor e a morte embalados pela música de Mercedes Sosa. A agonia e o sofrimento de trabalhadores rurais são retratados de modo poético na ligação com a terra e os seus frutos. Os corpos em movimento têm, como objeto mediador da cena, batatas que são posicionadas, atiradas pelo palco e guardadas em sacos. A ideia de mudança social está implícita na concepção dessa coreografia junto às mudanças da natureza, das idades, dos caminhos do homem. Mas há o sentimento genuíno e imutável do amor à terra, à humanidade, ao amado que sustenta os camponeses vivos e em harmonia na sua situação de desamparo e exploração (ver série A).

Da América Latina profunda e revolucionária o registro do espetáculo passa aos temas universais da modernidade urbana. A coreografia seguinte, Cherché, Trouvé, Perdú, do francês Patrick Delcroix, aborda os movimentos cotidianos que refletem $\mathrm{o}$ individualismo e a procura por liberdade nas desventuras do amor. A música erudita e sofisticada de Arvo Pärt e o palco como

\footnotetext{
${ }^{10}$ Depoimento apresentado no documentário de Nils Tavernier, Tout près des étoiles: les dauseurs de l'Opera de Paris, 2001.
} 
Bailarinas e bailarinos: uma etnografia da dança como profissão

cenário são o pano de fundo para tratar da busca do amor por meio do acaso, do encontro e de seu transcurso, mediado por aspirações individuais, afetivas e profissionais $e$ da privação intencional que se desencadeia no estado desorientado $e$ incerto de uma nova busca. Os bailarinos desenham na cena, com risco preciso, a poesia do jogo amoroso com o seu corpo e com os corpos dos outros e exprimem quando se movem as formas românticas da aposta, das seduções, da intensidade do amor, das tentativas de reaproximação e da perda (ver série $\mathrm{B}$ ).

E, por fim, para concluir o espetáculo, uma criação nacional de Rui Moreira: Trama. A temática dessa produção diz respeito à transcendente alegria do país. A coreografia animada pela música moderna de Lenine, Marco Suzano e Mestre Ambrosio remete ao misticismo e à observação de brincadeiras, festas populares, folguedos e personagens que são reveladores da complicada trama que caracteriza a corporalidade simples, desenvolta $e$ alegre do brasileiro. O ritmo dessa última apresentação é contagiante e faz com que a plateia termine a noite com vontade de dançar (ver série $\mathrm{C}$ ).

O espetáculo dura em torno de uma hora. Por volta das $22 \mathrm{~h} 30$, o público comovido e cheio de entusiasmo aplaude de pé, com assobios altos e gritos de "bravo". Os bailarinos, juntos, agradecem inclinando os corpos para baixo. Isso se repete algumas vezes na ininterrupta salva de palmas do público. Depois as cortinas são fechadas, a luz da plateia acende e os espectadores começam a se dispersar. Já é quase meia noite quando o dia de trabalho termina e todos precisam se recuperar do esforço físico, que é dobrado em dia de espetáculo por conta da adrenalina e da emoção.

$\mathrm{Na}$ manhã seguinte, às $9 \mathrm{~h}$ em ponto, o piano começa a tocar e os bailarinos despertam movimentando-se na aula de balé clássico para depois iniciar os ensaios das coreografias contemporâneas, que apresentarão na próxima noite de espetáculo. E é no ritmo dessa engrenagem que esses profissionais adquirem a modelagem corporal apropriada ao perfil da produção artística da Cisne Negro Cia. de Dança. 
Juliana Cunha Lima Neves

Série A
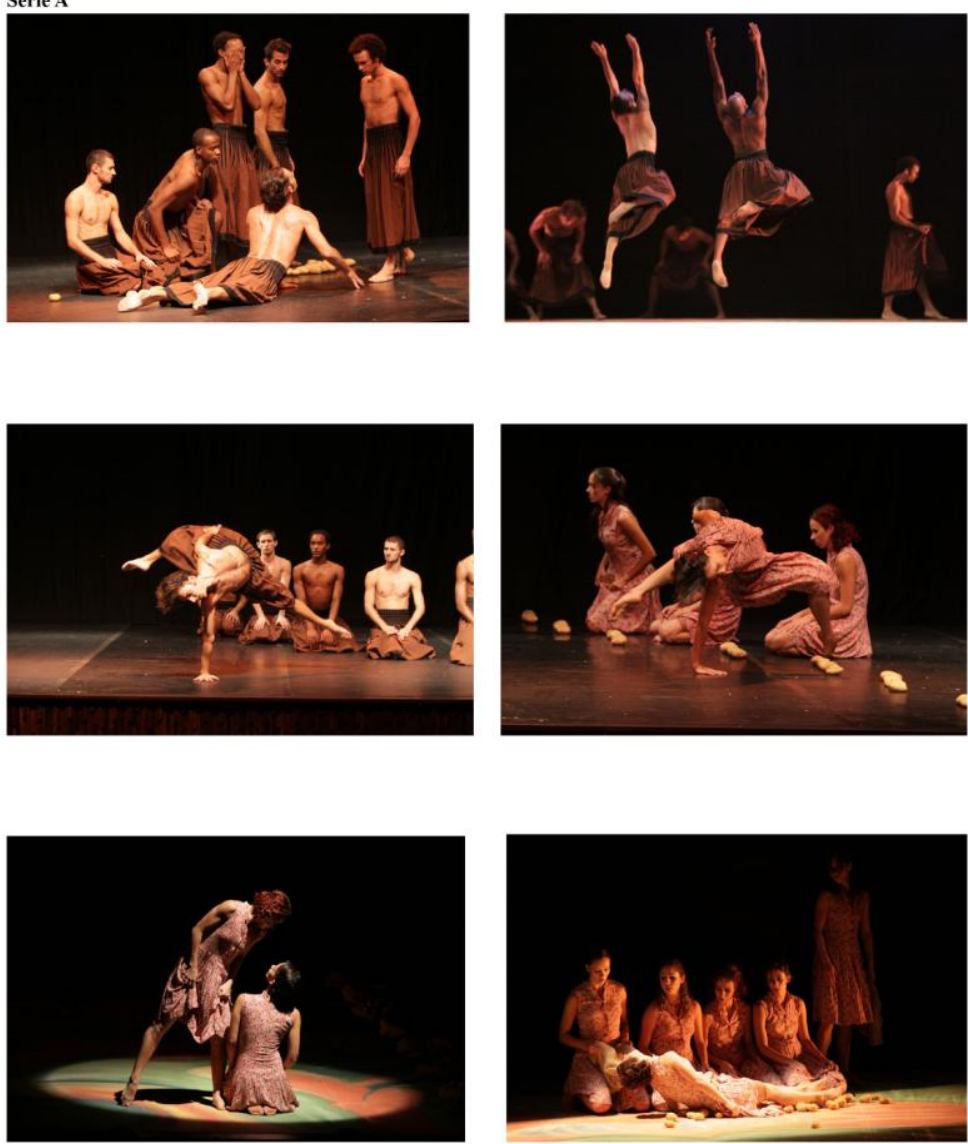
Bailarinas e bailarinos: uma etnografia da dança como profissão

Série B
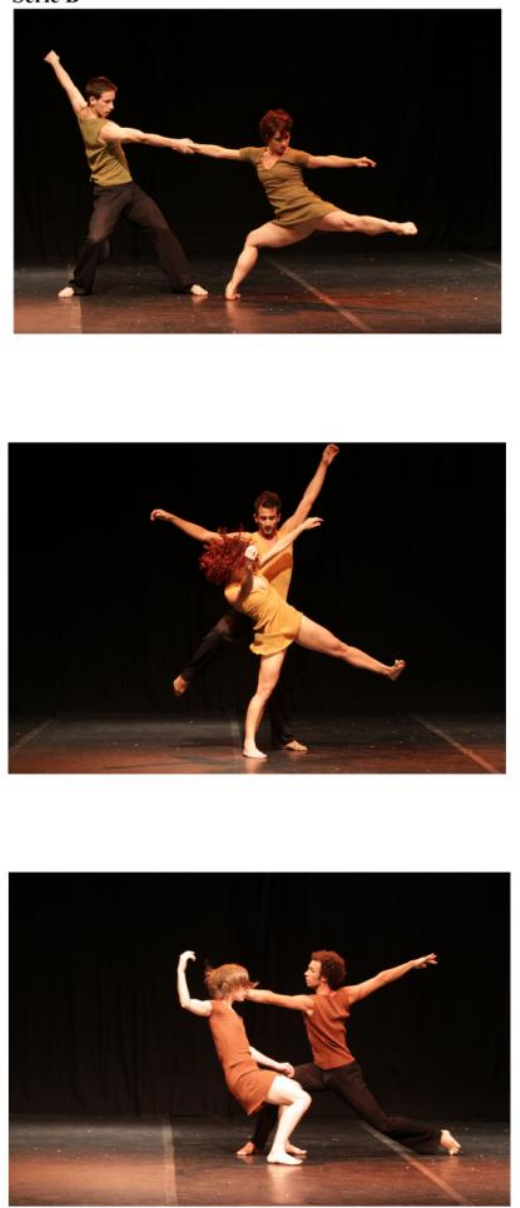
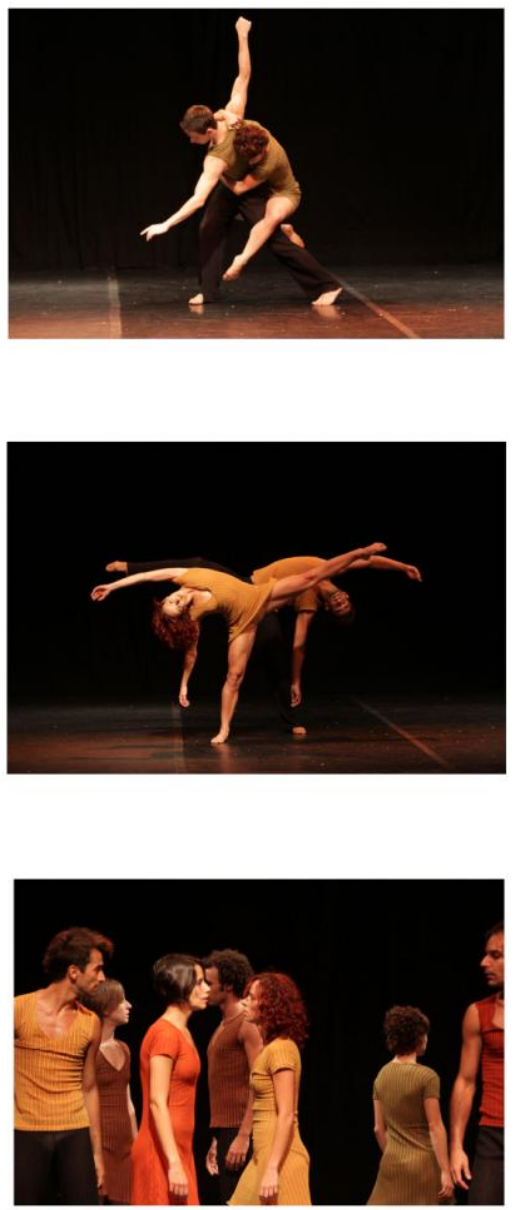
Juliana Cunha Lima Neves

Série C
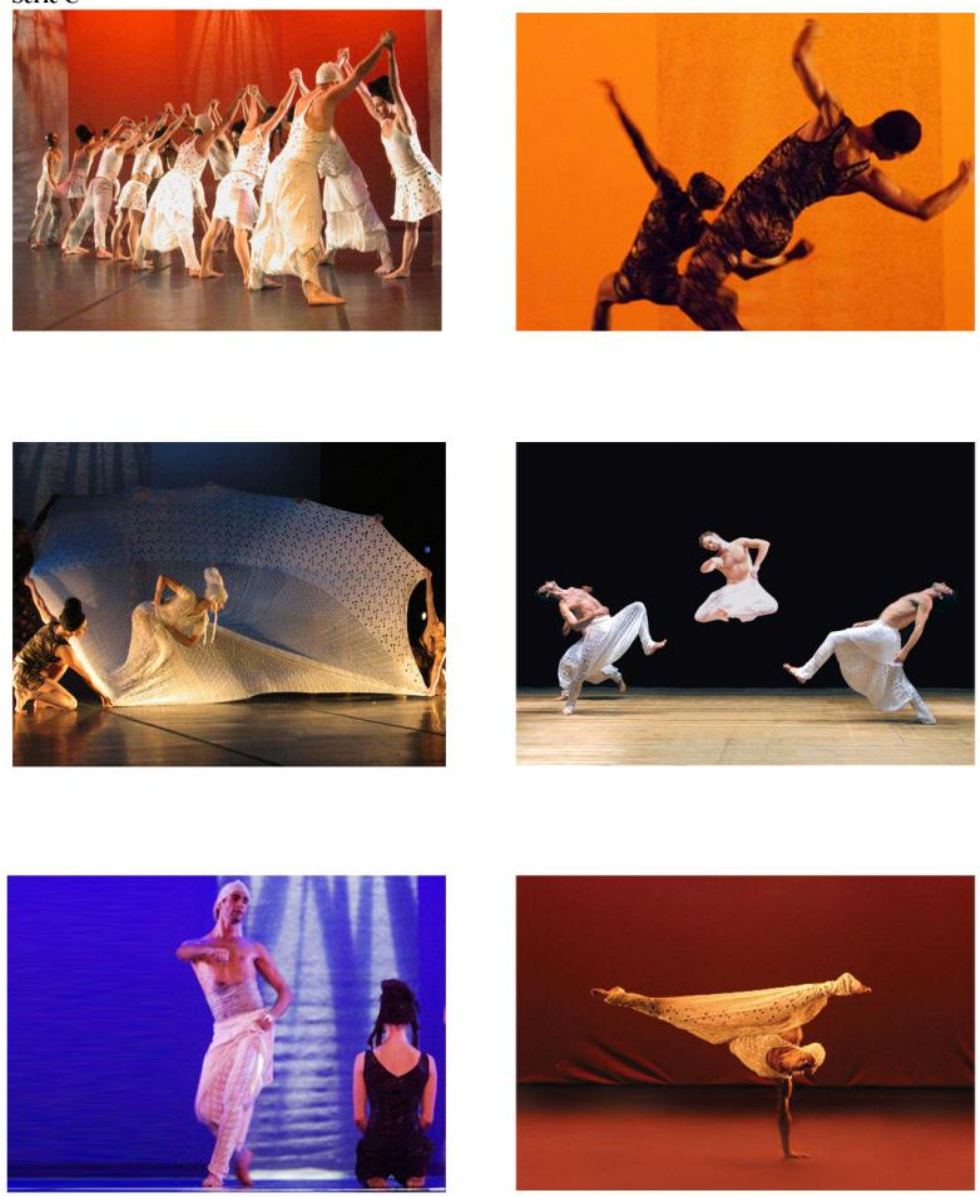
Bailarinas e bailarinos: uma etnografia da dança como profissão

\section{A "magia" da cena e a ética do asceta}

No balé clássico ocorre uma estilização profunda do corpo que o torna hábil para atuar profissionalmente e o modifica também no âmbito de seu dia a dia. O processo de aprendizagem da dança acadêmica implica a construção de corporalidades e também de subjetividades que constituem a experiência corporal mais ampla de boa parte dos bailarinos contemporâneos de nossos tempos.

A permanência na dança clássica e o exercício de seu treino diário produzem condições corporais físicas e estéticas que traçam uma identidade para o bailarino. A postura, a posição da cabeça, a rotação externa das pernas e o desenho definido de suas linhas são características que diferenciam os bailarinos, já que a feição adquirida não é a da vida cotidiana, e faz com que eles se reconheçam dentro e fora do mundo da dança (Mora, 2008a). Foi essa singular configuração corporal que fez com que alguns membros da direção e profissionais da companhia me percebessem como bailarina, o que facilitou minha inserção nessa pequena comunidade.

É também por meio dessa educação sistemática, repetitiva $e$ de imitação de passos programados que o bailarino faz a aquisição das técnicas que tornam o corpo virtuoso, flexível $e$ calculado. A força física e a habilidade desenvolvidas nessa formação em que o bailarino submete-se a um rígido processo de disciplinamento levam a um extremo domínio técnico do corpo que, por sua vez, desperta fortes sensações de segurança, prazer e liberdade. Essas relações de poder com o corpo no balé clássico "ocorrem como resultado das tecnologias que as produzem e que se mantêm em grande parte graças a essas sensações, fruto da efetividade dessas tecnologias" (Mora, 2008b).

No entanto, essa dimensão subjetiva não se restringe ao balé clássico, mas diz respeito, ainda que vivenciada de outra maneira, a outros estilos de dança. No ato físico da execução das técnicas clássicas na aula ou dos procedimentos contemporâneos 
no ensaio e, principalmente, no palco, esses profissionais acionam e são acionados pela relação entre mecanicismo e experiência subjetiva (Mora, 2008c) que produz, no manejo controlado do corpo e da emoção despendida, sentimentos íntimos e abstratos de poder e transcendência. E essa ligação que altera e dinamiza o corpo é também estimulada pelas disputas acirradas do universo da dança, pela intervenção de professores, diretores de ensaio, coreógrafos e pela presença do público.

Além disso, essas percepções físicas e psíquicas excedem a atividade mecânica e não agem apenas no corpo que está em ação coreográfica, mas também naqueles que já passaram por ela. No momento da observação de campo, que estive entre os bailarinos no interior de seu mundo, precisei lidar com uma espécie de abstinência e com estranhos sentimentos de frustração. $\mathrm{O}$ piano, o espaço, as músicas, os movimentos, as roupas, a atmosfera da sala $e$, sobretudo, os ritos do teatro e os espetáculos desencadearam em meu corpo os sentidos, as intuições e uma consciência que diziam respeito às minhas antigas experiências na dança.

Apesar de meu distanciamento de anos desse universo ${ }^{11}$ experimentei, nessa ocasião, modificações que trouxeram à tona para minha hexis corporal de pesquisadora feições mais nítidas de meu antigo corpo de bailarina amadora. Nesse período de imersão, meu corpo não parou de produzir as sensações de emoção, de ânimo e de prazer com a dança que, no entanto, não podiam se concretizar a não ser como atividade sublimada de quem deixou a dança e tornou-se socióloga. Procurei me utilizar de minha antiga e conhecida hexis corporal como recurso para me aproximar da Companhia e dos bailarinos. Por outro lado, tive que controlar o estado espiritual de minha interioridade que havia se apoderado ou sido apoderada por meu objeto de análise. Isto é, eu estava ali como pesquisadora e não como bailarina e era preciso assumir, portanto, certa "neutralidade axiológica" (Weber, 2001:361).

\footnotetext{
${ }^{11}$ Desde que me afastei do balé como atividade sistemática, não deixei de participar como bailarina amadora de cursos no Brasil e no exterior de balé clássico.
} 
Mas, no processo etnográfico o pesquisador está inserido no ambiente vivo e animado de seus dados de modo que o seu corpo "participa", em ação, da apreensão do objeto estudado. Mais ainda quando se trata de pensar diretamente o corpo, no caso, o do bailarino. Prestar atenção a um e com o corpo e aos outros corpos "amplia o campo no qual podemos procurar fenômenos de percepção e atenção, e sugere que prestar atenção ao corpo pode nos ensinar algo sobre o mundo e sobre os outros que nos rodeiam" (Csordas, 2008a:372). ${ }^{12}$ Cabe então considerar que o "campo de possibilidades interpretativas é contínuo entre observador e observado" (Csordas, 2008b:382).

No entanto, não é possível negligenciar no plano intersubjetivo da etnografia o diferente papel dos "corpos" em questão. Eu que havia abandonado a dança e seguido as ciências sociais estava ali para investigar os bailarinos que fazem da construção de tais subjetividades não um objeto de estudo da sociologia, mas um modo de vida. $\mathrm{O}$ que significa dar o corpo em sacrifício, porque é na submissão da aquisição e da efetivação do domínio técnico da dança, cujos processamentos implicam riscos, machucados, dores e lesões, que os bailarinos concretizam as relações de poder com o corpo que produzem sensações de difícil apreensão material de prazer, sensualidade, emoção e liberdade.

A construção de tais corporalidades e subjetividades é o resultado do dia a dia de trabalho desse profissional. E essas vivacidades capturadas pelo "sabor e a dor da ação" (Wacquant, 2002:11) são sentidas na rotina das aulas, dos ensaios e também dos espetáculos - momento em que atingem significado mágico. Da coxia à cena, como que em fração de segundos, esses sentimentos se aquecem, se agitam, transubstanciando-se em uma espécie poderosa de química que domina o corpo do bailarino e da qual ele ficará dependente. É no palco, dançando, que esses

\footnotetext{
${ }^{12} \mathrm{O}$ autor trata da dialética entre consciência perceptiva e prática coletiva buscando compreender a percepção como modos somáticos de atenção, que são maneiras culturalmente constituídas de estar atento a e com o corpo em espaços que incluem a presença corporificada de outros.
} 
jovens artistas experimentam, levando às últimas consequências, a transcendência ao plano subjetivo e sagrado dessa atividade. Essa experiência limite, que confere ao bailarino o seu papel de intérprete (Sorignet, 2001:363) é considerado por boa parte dos bailarinos entrevistados o "momento mágico" que faz valer à pena a profissão.

Os efeitos sobrenaturais da cena estimulados pela conexão de intensas sensações de prazer, comoção, sexualidade e poder com o corpo promovem fascínio e sedução por essa atividade. É isso que faz com que os bailarinos estabeleçam com a dança uma relação de paixão, na qual o sofrimento, os martírios e a violência do corpo são suplantados na medida em que o mesmo é invadido de entusiasmo e exaltação. A cena é como uma "droga" para o bailarino. ${ }^{13} \mathrm{E}$ o seu corpo interno na atmosfera encantada do palco torna-se adicto da experiência do nexo entre satisfação, delicadeza e agressão. A submissão e a dependência aos sacrifícios desse métier podem ser justificadas pelo abstrato sentimento de amor à dança.

Assim como a rotina de trabalho, a sensação mágica do palco e os breves minutos de glória que a cena promove são elementos centrais na direção e na ligação dos bailarinos à conduta de vida da dança como profissão. A ação, a disciplina e a resignação que permitem o domínio técnico do corpo de bailarino são qualidades que caracterizam a ascese do ethos coreográfico, por meio da qual esse profissional torna-se capaz de atingir o virtuosismo que o transportará ao nível sagrado, quase religioso dessa atividade. A ascese corporal da dança produz "estímulos psicológicos" que são uma poderosa alavanca para a inserção e a permanência na dança quando concebe o trabalho com o movimento coreográfico como uma vocação artística, como um meio para o bailarino eleito alcançar e se certificar de seu "estado

${ }^{13}$ Depoimento de bailarino no documentário de Nils Tavernier Tout près des étoiles: les danseurs de l'Opéra de Paris, 2001. 
Bailarinas e bailarinos: uma etnografia da dança como profissão

de graça" nesse mundo, ou dar sentido mágico, excepcional, à sua vida (Weber, 2006:116, 162). ${ }^{14}$

\section{Conclusão}

Os resultados da pesquisa revelaram que a construção da corporalidade e da subjetividade propiciada por essa atividade, apesar de estabelecer entre o bailarino e a dança uma relação de profunda intimidade, uma ligação de estreita afinidade entre a modelagem e os sentidos do corpo e esse universo não é, contudo, garantia para o acesso à profissão. A inclinação para esse mundo reside também na origem social, que é elemento relevante e plataforma para esse salto.

Entre amadores que praticam a dança encontram-se bailarinos oriundos de diversos segmentos sociais, entre os quais a presença das elites e das camadas médias instruídas não é de se negligenciar. Não obstante, no âmbito profissional, o recrutamento para a dança clássica contemporânea e, particularmente, para as companhias estáveis e consagradas do meio coreográfico é efetuado, sobretudo, entre as frações das camadas médias urbanas menos privilegiadas. $\mathrm{E}$ as distinções que as caracterizam, dizem respeito às questões de gênero $e$ ao grau de instrução $e$ de capital cultural.

\footnotetext{
${ }^{14} \mathrm{O}$ autor trata da qualidade ascética da doutrina protestante como uma valorização religiosa do trabalho profissional que se torna o recurso ascético supremo de comprovação e regeneração do ser humano e da autenticidade de sua fé. A ascese protestante promove o estímulo psicológico para a sistematização metódica da conduta de vida quando racionaliza o trabalho como vocação profissional, como uma maneira de garantir a salvação extramundana. É por meio do trabalho metódico, da ascese intramundana, que o protestante pode alcançar a salvação "extra" mundo. Utilizei-me dessa reflexão, guardadas as devidas proporções, para auxiliar na interpretação a respeito da atração pela dança. A experiência ascética do trabalho coreográfico viabiliza e tem como compensação o estado sagrado e subjetivo da cena, que suscita no bailarino uma espécie de sensação de "salvação" e de transcendência neste mundo.
} 
O mais numeroso grupo social entre os profissionais da dança é constituído pelas bailarinas que residem na cidade de São Paulo e habitam em bairros como Jabaquara, Interlagos, Planalto Paulista, Perdizes, Vila Mariana, Vila Beatriz. De um modo geral, mãe de bailarina é dona de casa. Já os pais trabalham em setores variados como, por exemplo, empresário de firma de rastreamento de veículo, operário qualificado da automobilística Basf, gerente de vendas de loja de carro, pequenos comerciantes - vendedores do círculo do livro da editora Abril e de material didático para escolas, $e$ assistente de enfermagem. As filhas desses profissionais formam um segmento pouco dotado de capital cultural e com nível médio de instrução. Poucas são as bailarinas que ingressam na universidade. Em contrapartida, todas concluíram o ensino fundamental e médio em instituições particulares.

A experiência dos homens convocados a atuar no mundo do espetáculo coreográfico é distinta da feminina. Atraídos pela possibilidade de viverem da dança no centro da metrópole paulistana, os bailarinos se deslocam de Brasília (DF), Sepetiba (RJ), São José dos Campos, Cotia (SP), entre outros, para trabalhar nos grupos legitimados da cidade. Uma vez empregados, os homens se organizam em repúblicas próximas ao endereço da sede das companhias ou em alojamentos proporcionados por elas. Muitas das mães desses jovens são também donas de casa e os pais ocupam atividades como pequeno comerciante, operário qualificado da Volkswagem, segurança, encarregado de estoque, cabo eleitoral de partido político. Boa parte dos bailarinos concluiu o ensino fundamental e médio em escolas públicas ou como bolsista de escolas privadas. Mas, salvo exceções, não apostam na universidade.

Diferente da carreira de músico erudito, na dança não há indícios significativos de herança cultural (Ravet, 2007:63). As bailarinas, assim como os bailarinos, não costumam ter parentes que atuaram como amadores ou profissionais no mundo coreográfico ou mesmo em outras artes. A formação no balé clássico ou em estilos considerados menos consagrados se 
Bailarinas e bailarinos: uma etnografia da dança como profissão

apresenta como uma oportunidade para o ingresso e lançamento na esfera da cultura. E por essa razão um dos principais atrativos para a dança é a presença de fatores de transgressão presentes nessa vocação, que fazem render carreiras femininas e masculinas no universo clássico da dança contemporânea.

A escolha pela dança como profissão tem relação com deslocamentos, com a reconversão, operada pelo corpo, de trajetórias prováveis. Essa é uma atividade cuja atuação de "corpo e alma" permite a superação da condição de existência, a conquista de uma nova identidade, a experimentação e a vivência de sexualidades que se concretizam no poder e no prazer de levar o corpo cada vez mais além de seus limites físicos ou sensíveis. Entre os bailarinos clássicos contemporâneos, a subversão não aparece como oposição ao sistema ascético e opressor a que estão submetidos, mas é a adesão a ele que leva às rupturas materializadas pelo corpo. A efetividade da própria técnica reside na possibilidade de transgressão:

girar e girar sobre a ponta de um pé é principalmente uma exibição de virtuosismo técnico, e o resultado de anos de uma prática disciplinar sobre o corpo; mas também significa para quem a executa, a experiência de burlar a lei da gravidade, de conhecer e manejar o próprio corpo, de criar e de fazer arte (Mora, 2009).

Da aprendizagem da dança redunda uma segunda formação do corpo, que vai produzir a transformação da hexis corporal tomada como suporte da mudança de rumo daqueles que se convertem em bailarinos profissionais e buscam traçar outro destino social. Ser bailarino é dar o seu corpo em espetáculo o que supõe a aceitação de exteriorizar-se e, portanto, de ter uma consciência satisfatória de si e da imagem que fazem de si (Bourdieu, 2002:117). A dança permite, pelo conhecimento e a elaboração de outro corpo, o desembaraço de seus constrangimentos e a aquisição de uma apreensão positiva dele. 
No envolvimento com esse novo corpo e com o seu ethos é que reside o ato subversivo.

Tornar-se bailarino é fazer da construção das corporalidades e subjetividades secretas à dança, fabricadas e sentidas na rotina dessa profissão, outros e novos modos de vida experimentados no cotidiano como liberdades conquistadas. E cujo sentimento extremo de transcendência se opera no palco, porque em cena é possível fazer coisas que não se faz na vida. Ser bailarino, na definição de uma estrela da Ópera de Paris, é, antes de tudo, ter "uma necessidade enorme de existência" e um meio de capacitála como estilo de vida.

\section{Referências bibliográficas}

BourdieU, Pierre. A distinção: crítica social do julgamento. São Paulo, Edusp/ Porto Alegre, RS, Zouk, 2007. . Le paysan et son corps. Le bal des célibataires: crise de la société paysanne en Béarn. Paris, Éditions du Seuil, 2002, pp.110-129.

CsORDAS, Thomas. Corpo, significado, cura. Porto Alegre, UFRGS, 2008.

FREUD, Sigmund. Os pensadores. São Paulo, Abril Cultural, 1978.

Hanna, Judith Lynne. Dança, sexo e gênero. Rio de Janeiro, Rocco, 1999.

LAPlanCHE, J.; PONTAlIS, J. Vocabulário de psicanálise. São Paulo, Martins Fontes, 1986, pp.637-641.

MAUSS, Marcel. As técnicas do corpo. In: MAUSS, Marcel. Sociologia e antropologia. São Paulo, Cosac \& Naif, 2003, pp.399-422.

PONTES, Heloisa. Intérpretes da metrópole: história social e relações de gênero no teatro e no campo intelectual, 1940 - 1968. São Paulo, Edusp, 2010.

RAVET, Hyacinthe. Devenir clarinettiste: carrières féminines en milieu masculin. Actes de la recherche en sciences sociales (168), Paris, Seuil, 2007, pp.50-67.

SORIGNET, Pierre-Emmanuel. La construction des identités sexuées et sexuelles au regard de la socialisation professionnelle: Les cas des 
Bailarinas e bailarinos: uma etnografia da dança como profissão

danseurs contemporains. Sociologie de l'art, opus 5, Paris, L'Harmattan, 2004, pp.11-34.

. Le métier de danseur contemporain. Thèse pour Le doctorat sous la direction de Gérard Mauger. Paris, Ecole des Hautes Etudes en Sciences Sociales, 2001.

WACQUANT, Loïc. Corpo e Alma: Notas etnográficas de um aprendiz de boxe. Rio de Janeiro, Relume Dumará, 2002.

Weber, Max. A ética protestante e o espírito do capitalismo. São Paulo, Cia. das Letras, 2004.

. O sentido da "neutralidade axiológica" nas ciências sociais e econômicas. In: WEBER, Max. Metodologia das ciências sociais (vol. 2). São Paulo, Cortez/Campinas, Editora da Universidade Estadual de Campinas, 2001, pp.361-398.

\section{Fontes}

MorA, Ana Sabrina. Danza, género y agencia. Practicas de oficio. Investigación y reflexión en Ciencias Sociales, (4), Instituto de Desarrollo Económico y Social/ Universidad Nacional de General Sarmiento (IDES/UNGS), Buenos Aires, 2009. Disponível em: $<$ http://www.ides.org.ar/shared/practicasdeoficio/2009nro4>.

. Cuerpo, sujeto y subjetividad en la danza clásica. Revista Question (17), Facultad de Periodismo y Comunicacíon Social/ Universidad Nacional de La Plata, 2008. Disponível em: $<$ http://perio.unlp.edu.ar/question $>$.

TAVERNIER, Nils, Tout près des étoiles: les danseurs de l'Opéra de Paris, França, 2001. [Documentário] 